\title{
СТАТИСТИЧНІ РЕЗУЛЬТАТИ ЕФЕКТИВНОСТІ ПРОГРАМИ ПСИХОЛОГІЧНИХ ПОСЛУГ ДЛЯ БАТЬКІВ ДІТЕЙ 3 ОСОБЛИВИМИ ПОТРЕБАМИ У ГРУПАХ «ВЗАСМОДОПОМОГИ»
}

УДК: 159.9. 616.

\section{Островсъка Катерина Олексї̈на}

Доктор психологічних наук, професор, завідувач кафедри корекиійної педагогіки та інклюзії Львівського національного університету ім. I. Франка, м. Львів (Украӥна)

\section{Андрейко Богданна Володимирівна}

Асистент кафедри корекиійної педагогіки та інклюзії Львівського національного університету ім. I. Франка, м. Львів (Україна)

\begin{abstract}
Анотація. Програма психологічної допомоги для батьків у групі психологічної підтримки батьків складається з етапів, які йдуть почергово. Етапи роботи: інформативний, діагностичний, психолого-консультативний, психотерапевтичний. Важливим, на сьогодні, $е$ чітке розуміння проблеми у відсутності психологічної допомоги батькам дітей з особливими потребами. У статті проаналізована теорія й методика соиіально-психологічної роботи з сім'єю. Після опрацьованих теоретичних засад та психологічних досліджень роботи з батьками дітей з особливими потребами, ми формуємо складний комплекс роботи з батьками, що спрямований на корекцією та стабілізаџію емоџійних станів у батьків, психотерапевтичної роботи над особистісно-мотиваиійною сферою, роботою над взаєминами у сім'ї. У роботі ми використовували основи та техніки з індивідуального та психологічного консультування та короткотермінову терапії зосереджену на виріменні BSFT. У статі детально та поетапно описано роботу та процес проведення короткотермінової терапії, основні їі принципи та засади. Обтрунтовано важливість і потрібність даної парадигми послуг саме в сфері неповносправності, статистично доведено ефективність роботи.
\end{abstract}

Ключові слова: батьки дітей з особливими потребами, індивідуальне та психологічне консультування, короткотермінова терапія зосереджена на вирішенні BSFT, моделі психологічної допомоги родинам, статистичний аналіз у психологічному дослідженні.

Постановка проблеми. Важливим, на сьогодні, $є$ чітке розуміння проблеми у відсутності психологічної допомоги батькам дітей 3 особливими потребами. Парадигма послуг для батьків дітей з особливими потребами, робить перші кроки в Україні. Ми пропонуємо нову 
ефективну модель (статистично доведено) i структуру парадигми психологічних та психотерапевтичних послуг для батьків дітей з особливими потребами. На основі різних принципів формувалися різноманітні моделі психологічної допомоги родинам осіб з особливими потребами.

Аналіз досліджень і публікацій. На основі різних принципів, а саме виховних, сімейно центрованих та мотиваційних, формувалися різноманітні моделі психологічної допомоги родинам осіб з особливими потребами. Модель Б.Ф. Скінера спиралися на принципи збільшення кількості та якості взаємодій -інтеракцій дитини і батьків. Модель В. Є. Кагана, спирається на принцип стимулювання батьків до виникнення у них забутих інтересів і захоплень. На думку автора для них як осіб, для їх роботи з дитиною необхідне повернення до улюбленої роботи і до себе. Сутність моделі полягає в дотриманні терапевтичної дистанції без відмови від просто людського контакту з батьками. Модель Х. Джайнотта спілкування батьків з дітьми спирається у всіх ситуаціях батьки підтримують позитивний образ «Я» у дитини; уникають особистісних негативних оціночних суджень. Модель В. В Тарасун спирається на принцип вирішення проблеми раннього прогнозування і своєчасного запобігання труднощів у навчанні дітей 3 особливими потребами. Важливого значення при побудові стратегії надання психологічної допомоги сім'ям, які виховують дитину з осо- бливими потребами, мають базові положення теорій: психолого-педагогічних закономірностей розвитку дитини з психофізичними порушеннями як результату складного процесу його соціалізації (Т. А. Власова, Л. С. Виготський, В. І. Лубовський, Д.Б. Ельконін) та розвитку в умовах дизонтогенезу, який потребує створення спеціального корекційнорозвиваючого середовища (К. С. Лебединська, В. В. Лебединський, І. Ю. Левченко, В.І. Лубовський,С. М. Мастюкова, М. С. Певзнер, В.Г. Петрова, С. Я. Рубінштейн, У. В. Ульєнкова). Під спеціальним корекційнорозвиваючим середовищем в сім'ї мається на увазі внутрішньосімейні умови, які створюються батьками і забезпечують оптимальний розвиток дитини з психофізичними недоліками.

Теорія й методика соціальнопсихологічної роботи з сім'єю, яка виховує дитину 3 обмеженими можливостями (К. О. Островська, І. Іванова, І. Коробейников, А. Маллєр, I. Мамайчук, В. Мартинов, О. Мастюкова, Г. Мішина, Н. Фінні, Л. Ханзерук та ін).

Виклад основного матеріалу. Програма психологічної допомоги для батьків у групі психологічної підтримки батьків складається 3 етапів, які йдуть почергово. У роботі ми використовували основи та техніки 3 індивідуального та психологічного консультування та короткотермінову терапії зосереджену на вирішенні BSFT. Етапи роботи: 
- Інформаційний. Етап спрямований на надання інформації про виховання дитини 3 особливими потребами;

- Діагностичний. Діагностування сімейної пари, з використанням психологічних методик на визначення емоційних станів, особливостей особистості та хронічної втоми, а також з використанням Біографічного методу.

- Психолого-консультативний. Надання психологічної допомоги батькам за допомогою технік сімейного консультування, які покращують їхній емоційний стан, сприяють адаптації до народження дитини 3 особливими потребами та її прийняттю, покращують характер взаємин і загалом стосунки в сім’ї і дають змогу відпочити, і позбавитися хронічної втоми та почуття провини у майбутньому.

Концепція власної парадигми послуг для батьків дітей 3 особливими потребами включає в свою структуру два блоки психолого-консультативний та психотерапевтичний (проводяться в групі, індивідуально та сімейно в парі):

- Перший блок. Програма тренінгу для батьків у групі психологічної підтримки батьків; методика Керол Саттон - робота 3 «важкою поведінкою» дитини;

- $\quad$ Другий блок допомоги батькам дітей 3 особливими потребами у групі психологічної підтримки батьків з використанням Короткотермінової терапії сконцентрованої на розв'язанні - Centrum terapii krotkoterminowey, member of European

\section{Brief Therapy Association.}

Перший блок - програма психологічної допомоги для батьків. Група психологічної підтримки батьків. Програма для батьків у групі психологічної підтримки батьків складається 3 етапів, які йдуть почергово. У роботі ми використовували основи та техніки з індивідуального та сімейного психологічного консультування. Етапи роботи спрямовані на надання інформації про виховання дитини, діагностування сімейної пари, надання психологічної допомоги батькам за допомогою технік сімейного консультування, які покращують їхній емоційний стан, сприяють адаптації до народження дитини $з$ особливими потребами та іiі прийняттю, покращують характер взаємин і загалом стосунки в сім’ї і дають змогу відпочити, і позбавитися хронічної втоми у майбутньому. Також у роботі ми використовували біографічний метод, який є феноменологічним дослідженням і у свою чергу має наступні проектвині методики: «лінія життя», «моя автобіографія», «гра біографічна» - Дуче Діметріо, які поєднують у собі діагностичний та психотерапевтичний науковий результат, який позитивно впливає та покращує взаєморозуміння у сімейної пари, шляхом навіювання спогадів, знайомства заново, повернення до періоду зародження сім'ї і своєрідного ранжування подій, і пророчення та бажань на майбутнє.

Другий блок допомоги батькам дітей 3 особливими потребами: Психотерапевтична 
робота 3 батьками дітей з особливими потребами 3 використанням короткотермінової терапії сконцентрованої на розв'язанні. Короткотермінова терапія сконцентрована на розв'язанні - Centrum terapii krotkoterminowey, member of European Brief Therapy Association. Проводиться, як і в групі так і індивідуально.

В нашій роботі з батьками, які виховують дітей з особливими потребами, ми використовуємо основні принципи та техніки короткотермінової терапії, що скерована на розв'язок. Короткотермінова терапія зосереджена на вирішенні проблеми може проводитися як в групі так і індивідуально.

Основні концепції:

Короткотерміновість - робити тільки те, що потрібно, сконсентровані на будуванні розв'язання.

Розв'язання - спосіб, який звільнить клієнта від проблеми. Життя в якому нема проблем, будуємо добре життя. «Як буде виглядати твоє життя, коли ти будеш спокійний, чи щасливий» - уявлення цього вже є вирішення.

Клієнт змінив мислення і сам змінив свої проблеми.

Термін «Короткотерміновість» означає робити тільки те, що потрібно, сконцентрованість на будуванні розв'язку. Розв'язок - спосіб, який звільнить клієнта від проблеми і допоможе йому сконструювати життя, в якому нема проблем $[5 ; 6 ; 7 ; 8 ; 9 ; 10 ; 11 ; 12 ; 13 ; 14$; $15]$.
Робота в цьому напрямку є досить проста та ефективна. Короткотермінова терапія скерована на розв'язок відрізняється від інших підходів тим, що вона не концентрується на проблемі (діагнозі клієнта), оскільки це не лише не допомагає, але, часом і створює перешкоди клієнтові у поступі до вирішення цієї ж проблеми.

Перспектива корекційної роботи скерована є на теперішнє та майбутнє. Якщо випливає досвід минулого, то його використовується на користь досягнення певних цілей у вище згаданих перспективах.

Центральна філософія короткотермінової терапії скерованої на вирішення дивує своєю простотою. Проте, застосування таких простих правил вимагає від спеціалістів, які цей метод застосовують, самодисципліни та докладання чималих зусиль.

Сесія та етапи роботи практично не змінні протягом останніх років і беруть основу із напрацювань Інсу Кім берг та Стів Де Шейзер (I. K. Berg, S.De Shazerem, 1997) [5; 6; 7]. Отже, сесія (основні етапи роботи) складаються: Розмова вільна від проблем; Очікування: 3'ясування проблеми; Формулювання мети; Запитання про винятки; Запитання про чудо; Запитання про винятки; Оцінювання, шкалування; Перерва; Зворотна інформація: Компліменти; Обгрунтування; Домашнє завдання.

Відгук, з уст терапевта в SFBT - це обдуманий комплімент, який підкреслює ресур- 
си, сильні сторони і реалізовані зміни, зауважені впродовж дня, що повинні допомогти пацієнтові досягти поставленої мети. Пацієнти обмінюються відгуками, складеними під час перерви. Терапевт у відгуку підкреслює якості і досягнення пацієнта, які можуть мати значення з точки зору пошуку або реалізації мети. Для пацієнта відгук є підбадьоренням на закінчення дня терапевтичної роботи. Відгук мусить бути позитивним і стосуватись конкретних ситуацій про які пацієнт розповідав того дня [6, с. 15-16].

Для того, щоб з'ясувати, чи була ефективною проведена психокорекційна та психотерапевтична робота 3 батьками, здійснено порівняльний аналіз показників їх емоційної сфери та особливостей батьківського ставлення до та після зазначених вище психологічних впливів.

Для цього було використано математико-статистичний критерій Вілкоксона, який враховує не тільки напрям, а й інтенсивність зсувів значень досліджуваних ознак і належить до непараметричних методів, що найбільш прийнятні, коли обсяг вибірок невеликий (пакет STATISTICA 6.0, модуль Nonparametrics / Comparing two dependent samples (variables). Статистично значущі відмінності до та після проведеної психотерапевтичної роботи виявлено за такими показниками: прийняття і допомога суспільства ( $\mathrm{p}=0,0006)$, настрій $(p=0,0041)$, тривожність $(p=0,0001)$, депресія $(p=0,0039)$, прийняття $(p=0,0001)$, си- мбіоз ( $p=0,0007)$, кооперація ( $p=0,0000)$, маленький невдаха $(\mathrm{p}=0,0000)$, хронічна втома $(\mathrm{p}=0,0001)$, фізичний дискомфорт $(\mathrm{p}=0,0000)$, когнітивний дискомфорт $(\mathrm{p}=0,0000)$, зниження мотиву соціального спілкування $(p=0,0483)$.

У батьків дітей із особливими потребами підвищився рівень позитивного настрою, оскільки вони пройшли психотерапевтичну практику.

Порівняльний аналіз виявив суттєві позитивні зміни щодо таких негативних емоційних станів, що переживають батьки з особливими потребами раннього віку як тривожність та депресія (рис.1). Варто нагадати, що інтерпретувати результати за методикою визначення тривоги і дипресії потрібно згідно оберненого принципу: чим вищий показник, тим краще, тим менші прояви згаданих ознак. Зростання показників за шкалою

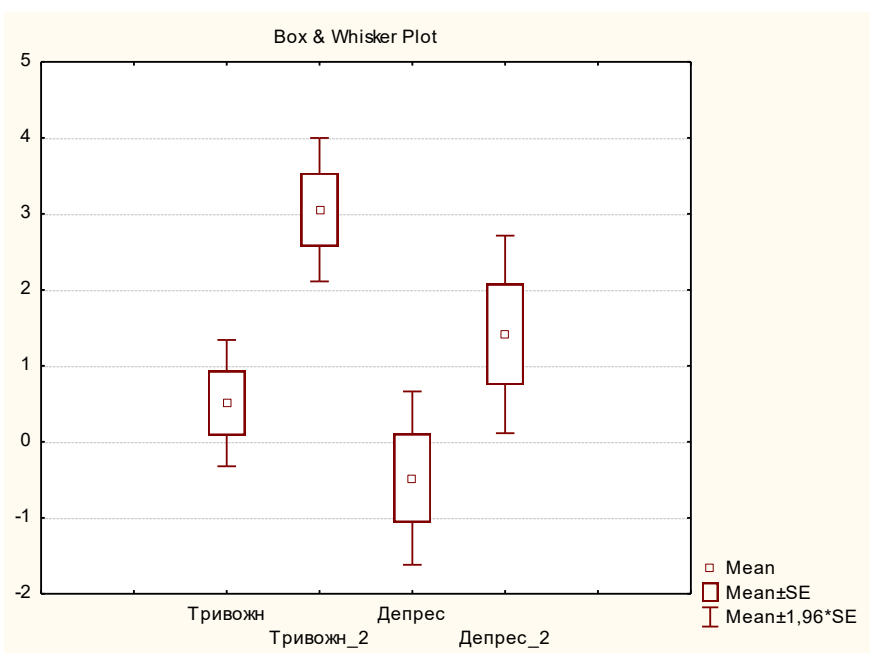

Рис. 1. Значення показників «тривожність та депресія» до і після психокорекційної та психотерапевтичної роботи 
«тривожність» та «депресія» після психологічної роботи з батьками свідчать про суттєве покращення їх стану.

За результатами психокорекційної та психотерапевтичної роботи з батьками дітей 3 особливими потребами спостерігаються позитивні зміни батьківського ставлення. А саме, зріс рівень прийняття, кооперації, симбіозу та знизився рівень сприйняття власної дитини як маленької невдахи. Це свідчить про те, що батьки переосмислили своє ставлення до дитини, приймають іiі такою, як вона $\epsilon$. Рівень прийняття свідчить про те, що батьки поважають індивідуальність дитини, симпатизують ій, прагнуть проводити багато часу з дитиною, схвалюють іiі інтереси та плани. Зростаюча кооперація свідчить про зацікавленість в справах і планах дитини, схвалення ініціативи та самостійності дитини, прагнення бути $з$ нею на рівних. Батьки бачать дитину з особливими потребами та її ресурсність, а не неповносправність.

Особливо значущими результатами $є$ також зафіксовані позитивні зрушення після проведеного комплексу психокорекційної та психотерапевтичної роботи з батьками дітей 3 особливими потребами щодо таких параметрів як хронічна втома (рис.2), фізичний та когнітивний дискомфорт та мотиву соціального спілкування.

Доведено, що одним із чинників порушення емоційної сфери батьків дітей з особливими потребами $є$ наявність/відсутність діаг-

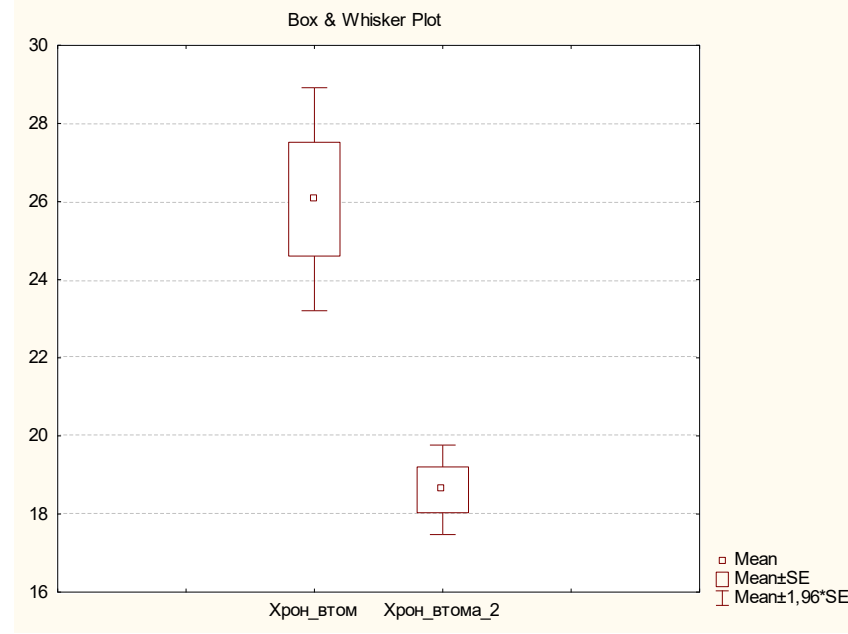

Рис. 2. Значення показника «хронічна втома» до і після психокорекційної та психотерапевтичної роботи

нозу захворювання. Батьки, що мають дітей 3 особливими потребами без встановленого діагнозу, постійно перебувають у невизначеному стані, що в свою чергу супроводжується депресією, роздратованістю, образою на інших та негативізмом. Відсутність встановленого діагнозу захворювання дитини опосередковано впливає на порушення емоційної сфери батьків та підвищує їх рівень хронічної втоми. А наявність діагнозу, в свою чергу, сприяє процесу прийняття батьками дитини такою, якою вона є. За допомогою регресійного аналізу виявлено, що вагомими детермінантами та основними чинниками порушення емоційного стану батьків дітей з особливими потребами є: постановка кінцевого діагнозу, яка в окремих сім'ях може тривати від народження дитини i до п'яти років через наявність множинних комплексних порушень; почуття провини, яке 
переслідує батьків і породжує негативні та деструктивні емоційні стани; фрустрація та хронічна втома, яку відчувають і переживають батьки у період виховання особливої дитини. Очевидним для нас, у практичній роботі з батьками, є допомога у боротьбі з названими чинниками, за допомогою діагностичних, iнформативних, консультативних та психотерапевтичних методів.

Висновки. Емоційні стани, батьківське ставлення, соціально-сімейні стосунки та хронічну втому можна змінити в результаті психологічної та психотерапевтичної допомоги, що була поділена на блоки з урахуванням індивідуальності кожної сім'ї: групової роботи, індивідуального та сімейного консультування а також короткотермінової психотерапії для батьків дітей з особливими потребами. На виховну ефективність впливають чинники: знання батьками психології дитини, вірна оцінка їі індивідуальних якостей, адекватний емоційний відгук на поведінкові реакції дитини, вибір підходящого способу взаємодії з дитиною, який найкраще відповідає іiі індивідуальним особливостям. Виховна ефективність, на нашу думку, може відбуватися лише за умов емоційної стабільності батьків, після їхнього примирення з хворобою дитини і відкритті в собі особистих ресурсів, на що має бути спрямована професійна психологічна допомога батькам.

Після короткотермінової терапії батьки дітей з особливими потребами розуміють, про необхідність організації процесу виховання і лікування дитини, саме поетапно і маленькими кроками. Основне, що у них змінюється світобачення і міняється мислення у позитивну сторону. Вміння бачити позитивне у будь якій ситуації дарує людині щасливі моменти життя. Завдяки технікам та етапам роботи короткотермінової терапії, батьки вже знають, що можна зробити ще, чого вже не потрібно робити, з ким необхідно порадитись. За допомогою такої техніки як шкалування (пропозиція розмістити себе на шкалі від 1 до 10) проблеми, вони бачать де $\epsilon$ зараз, що саме зробили, а що ще можна зробити. Батьки переносять свої слова, мрії та уявне почуття щастя на поведінку, що є ключовим аспектом нашої роботи. Вони відчувають цілковиту мить спокою, щастя, емоційної рівноваги, сімейного взаєморозуміння. Важливий аспект такої психотерапії це - розуміння самостійності у вирішенні своїх проблем а головне мотивації до вирішення, до успіху і щасливого життя у вигляді проходження усіх стадій адаптації народження дитини $з$ неповносправністю. Розробка й апробація моделі психологічної та психотерапевтичної допомоги для батьків охоплює всі аспекти, починаючи від психологічної діагностики психоемоційних станів та підбору методів для їх покращення та корекції переживань. Ефективність впливу має на меті також і забезпечення нормального функціонування дитини 3 психофізичними розладами у сім'ї та суспільстві. Компоненти нової та ап- 
робованої парадигми психологічних та психотерапевтичних послуг, а також етапність їх виконання, результатом реалізації якої є покращення та оптимальні емоційні стани, переживання та сприятливий клімат у см’ї батьків дітей 3 особливими потребами, соціалізація батьків та дитини за допомогою групи «Психологічної та психотерапевтичної допомоги».

Після проведеної психотерапевтичної роботи у батьків покращився настрій, знизилася тривожність та депресія, значно покращилося прийняття дитини, симбіозу, кооперації, знизилися значення хронічної втоми, фізичного та когнітивного дискомфорту, збільшився мотив соціального спілкування та взаємодії. В результаті ми отримали низку результатів, які мають важливе наукове та прикладне значення і будуть стимулювати як постановку нових експериментальних досліджень, так і розробку наукових основ психологічного та психотерапевтичного супроводу батьків дітей з особливими потребами раннього та середнього віку.

\section{Перелік використаних джерел:}

1. Душка А. Л. Роль сім’ї у соціалізації неповносправної дитини. / А.Л. Душка // Наука і освіта. - Одеса, 2009. № 1-2. - C. 48-52.

2. Ейдемиллер Е. Психология и психотерапия семи / Е. Ейдемиллер, В. Юстицкис. - 3-е изд. - СПб.: Питер, 2002. $-656 \mathrm{c}$.

3. Железняк Л. С. Опыт включения детей с проблемами развития в состав психотерапевтических групп / Л. С. Железняк, И. Б. Карвасарская // Обозрение психиатрии и мед. психологии. - 1993. - № 1. - С. 102-104.

4. Островська К. О. Психологічні особливості ставлення матерів до їх здорових дітей та дітей з обмеженими можливостями / К.О. Островська // Науковий часопис НПУ ім. М. П. Драгоманова : збірник наукових праць ; за ред. В. М. Синьова.- К. : НПУ ім. М. П. Драгоманова, 2015. - Вип. 29. - Сер. № 19. Корекційна педагогіка та спеціальна психологія. - С. 213-219.

5. Insoo Kim Berg, Peter de Jong, Terapia krótkoterminowa skoncentrowana na rozwiązaniu. [Електронний peсурс]. - Режим доступу: http://www.ctsr.pl/literatura

6. Grzyb M., Aletrnativni_modeli likuvannya_uzalezhnen. Parzymiechach 2014

7. Judith Milner, Patrick O’Byrne. Poradnictwo krótkoterminowe: narracje i rozwiązania.Wydawnictwo: Zysk i Ska; PoznańRok wydania: 2007

8.Kienhuis J., Świtek T. Klient ekspertem. Podejście Skoncentrowane na Rozwiązaniach i jego zastosowanie w Polsce. Wydawnictwo: Kraków Rok wydania: 2007

9. Kosman T., Założenia terapii skoncentrowanej na rozwiązaniach, „Warmińsko-Mazurski Kwartalnik Naukowy, Nauki społeczne» 1/2013 / KosmanT. [Електронний ресурс]. - Режим доступу: http:// cejsh.icm.edu.pl/cejsh/element/bwmeta1.element.desklight118f75d9-84af-407e-8f46-b256177ef2f1/c/

Kwartalnik1_2013_1.pdf.

10. Sczepkowski J., Terapia młodzieży z problemem narkotykowym. Podejście skoncentrowane na rozwiązaniach, Toruń 2007. - 159 s.

11. Sharry J., Madden B., Darmody M., W poszukiwaniu rozwiazan. Przewodnik po terapii krotkoterminowej,

Łódz 2007

12. Sutton $C$. Jak radzić sobie z trudnymi zachowaniami u dzieci (Cykl 8 książeczek) / Carole Sutton ; red. Ryszard Praszkier ; tł. Danuta Golec. - Warszawa : Fundacja "Synapsis", 1992.

13. Terapia krótkoterminowa BSFT - poszukiwanie rozwiązań. Rozmowa ze Steve'em de Shazerem, artykuł Wydawnictwo: "Nowiny psychologiczne", 3/1999 / De 
Shazerem S. [Електронний ресурс]. - Режим доступу: http://www.psttsr.pl/literatura-o-tsr,36

14. Tomasz Ś. Ścieżki rozwiązań. Wydawnictwo: Księgarnia Akademicka; Rok wydania: 2009

15. Trzebinska E. Psychologia pozytywna, Warszawa 2008.

16. Twardowski A. Sytuacja rodzin dzieci niepełnosprawnych / A. Twardowski; [red. I. Obuchowska] // Dziecko niepełnosprawne w rodzinie. - Warszawa : WSiP., 1991. - S.18-54.

\section{References (Transliteration):}

1.Dushka A. L Rol sIm'Yi u sotsIalIzatsIYi nepovnospravnoYi ditini. / A.L. Dushka // Nauka I osvIta. - Odesa, 2009. - \# 1-2. - S. 48-52.

2. Eydemiller E. Psihologiya i psihoterapiya semi / E. Eydemiller, V. Yustitskis. - 3-e izd. - SPb.: Piter, 2002. - 656 s.

3. Zheleznyak L. S. Opyit vklyucheniya detey s problemami razvitiya $v$ sostav psihoterapevticheskih grupp / L. S. Zheleznyak, I. B. Karvasarskaya // Obozrenie psihiatrii i med. psihologii. - 1993. - \# 1. - S. 102-104.

4. Ostrovska $K$. O. PsihologIchnI osoblivostI stavlennya materIv do Yih zdorovih dItey ta dItey z obmezhenimi mozhlivostyami / K.O. Ostrovska // Naukoviy chasopis NPU Im. M. P. Dragomanova : zbIrnik naukovih prats ; za red. V. M. Sinova.- K. : NPU Im. M. P. Dragomanova, 2015. - Vip. 29. - Ser. \# 19. KorektsIyna pedagogIka ta spetsIalna psihologIya. - S. 213-219.

5. Insoo Kim Berg, Peter de Jong, Terapia krótkoterminowa skoncentrowana na rozwiązaniu. [Електронний peсурс]. - Режим доступу: http://www.ctsr.pl/literatura

6. Grzyb M., Aletrnativni_modeli likuvannya_uzalezhnen. Parzymiechach 2014

7. Judith Milner, Patrick O’Byrne. Poradnictwo krótkoterminowe: narracje i rozwiązania.Wydawnictwo: Zysk i Ska; PoznańRok wydania: 2007

8. Kienhuis J., Świtek T. Klient ekspertem. Podejście Skoncentrowane na Rozwiązaniach i jego zastosowanie w Polsce. Wydawnictwo:
Rok wydania: 2007

9. Kosman T., Założenia terapii skoncentrowanej na rozwiązaniach, „Warmińsko-Mazurski Kwartalnik Naukowy, Nauki społeczne» 1/2013 / KosmanT. [Електронний ресурс]. - Режим доступу: http:// cejsh.icm.edu.pl/cejsh/element/bwmeta1.element.desklight118f75d9-84af-407e-8f46-b256177ef2f1/c/

Kwartalnik1_2013_1.pdf.

10. Sczepkowski J., Terapia młodzieży z problemem narkotykowym. Podejście skoncentrowane na rozwiązaniach, Toruń 2007. - 159 s.

11. Sharry J., Madden B., Darmody M., W poszukiwaniu rozwiazan. Przewodnik po terapii krotkoterminowej,

Łódz 2007

12. Sutton $C$. Jak radzić sobie $\mathrm{z}$ trudnymi zachowaniami u dzieci (Cykl 8 książeczek) / Carole Sutton ; red. Ryszard Praszkier ; tł. Danuta Golec. - Warszawa : Fundacja "Synapsis", 1992.

13. Terapia krótkoterminowa BSFT - poszukiwanie rozwiązań. Rozmowa ze Steve'em de Shazerem, artykuł Wydawnictwo: "Nowiny psychologiczne", 3/1999 / De Shazerem S. [Електронний ресурс]. - Режим доступу: http://www.psttsr.pl/literatura-o-tsr,36

14. Tomasz Ś. Ścieżki rozwiązań. Wydawnictwo: Księgarnia Akademicka; Rok wydania: 2009

15. Trzebinska E. Psychologia pozytywna, Warszawa 2008

16. Twardowski A. Sytuacja rodzin dzieci niepełnosprawnych / A. Twardowski; [red. I. Obuchowska] // Dziecko niepełnosprawne w rodzinie. - Warszawa : WSiP., 1991. - S.18- 54.

\section{Ostrovskaya Katerina}

Doctor of Psychology, Professor, Head of the Department of Corrective Pedagogy and Inclusion of the I. Franko Lviv National University, Lviv (Ukraine)

\section{Andreiko Bogdanya}

Assistant of the Department of Corrective Pedagogy and Inclusion of I. Franko Lviv National University, Lviv (Ukraine) 
STATISTICAL RESULTS OF THE EFFECTIVENESS OF THE PROGRAM OF PSYCHOLOGICAL SERVICES FOR PARENTS OF CHILDREN WITH SPECIAL NEEDS IN THE GROUPS OF «MUTUAL ASSISTANCE»

\section{ABSTRACT}

The program of psychological assistance for parents in the group of psychological support for parents consists of stages that go alternately. Stages of work: informative, diagnostic, psychological and consultative, psychotherapeutic. Important, for today, there is a clear understanding of the problem in the absence of psychological assistance to parents of children with special needs. The article analyzes the theory and method of social psychological work with the family. After working out theoretical foundations and psychological studies of working with parents of children with special needs, we form a complex complex of work with parents aimed at correction and stabilization of emotional states in parents, psychotherapeutic work on the personality-motivational sphere, work on familyrelated relationships. In this work, we used the basics and techniques of individual and psychological counseling and therapy BSFT. The article describes in detail and in stages the work and process of short-term therapy. The importance and necessity of this paradigm of services in the sphere of disability is substantiated and the efficiency of work is statistically proved.

Key words: parents of children with special needs, individual and psychological counseling, therapy BSFT, model of psychological care for families, statistical analysis in psychological research.

\section{Островская Екатерина Алексеевна}

Доктор психологических наук, профессор, заведующий кафедрой коррекиионной педагогики и инклюзии Львовского национального университета им. И. Франко, г. Львов (Украина)

\section{Андрейко Богданна Владимировна}

Ассистент кафедры коррекииионной педагогики и инклюзии Львовского национального университета им. И. Франко, г. Львов (Украина)

\section{СТАТИСТИЧЕСКИЕ РЕЗУЛЬТАТЫ ЭФФЕКТИВНОСТИ ПРОГРАММЫ ПСИХОЛОГИЧЕСКИХ УСЛУГ ДЛЯ РОДИТЕЛЕЙ ДЕТЕЙ С ОСОБЫМИ ПОТРЕБНОСТЯМИ В ГРУППАХ «ВЗАИМОПОМОЩИ»}

Аннотация. Программа психологической помощи для родителей в группе психологической поддержки родителей состоит из этапов, которые идут поочередно. Этапы работы: информативный, диагностический, психолого-консультативный, психотерапевтический. Важным, на сегодня, является четкое понимание проблемы в отсутствии психологической помощи родителям детей с особыми потребностями. В статье проанализирована теория и методика социальнопсихологической работы с семьей. После обработанных теоретических основ и психологических исследований работы с родителями детей с особыми потребностями, мы формируем сложный комплекс работы с родителями, направленный на коррекцией и стабилизации 
эмоциональных состояний у родителей, психотерапевтической работы над личностномотивационной сферой, работой над отношениями в семье. В работе мы использовали основы и техники по индивидуальному и психологического консультирования и краткосрочную терапии сосредоточенную на решении BSFT. В статье подробно и поэтапно описано работу и процесс проведения краткосрочной терапии, основные ее принципы и основы. Обоснованно важность и нужность данной парадигмы услуг именно в сфере инвалидности, статистически доказано эффективность работы.

Ключевые слова: родители детей с особыми потребностями, индивидуальное и психологическое консультирование, краткосрочная терапия сосредоточена на решении BSFT, модели психологической помощи семьям, статистический анализ в психологическом исследовании. 